Davin Helkenberg

University of Western Ontario, London, Ontario, Canada

\title{
Reading for Alternatives: The Experiences of Young Women Who Read Sexuality-Themed Fiction Online
}

\begin{abstract}
This paper examines the reading experiences and practices of young women who read sexualitythemed Young Adult Literature online. The findings of this study reveal that young women tend to seek out fiction in online spaces when they have reading interests or questions about sexuality that are not addressed in conventional Young Adult Literature. These readers reported that, from an early age, they sought out literature online that had explicit sexual content or focused on nonnormative topics such as LGBTQ relationships. They also identified comments sections as a significant aspect of their online reading experience which led to a sense of belonging to a reading community that is transparent, supportive and constructive about topics of sexuality.
\end{abstract}

\section{Introduction}

This paper examines the reading experiences and practices of young women who read sexualitythemed Young Adult (YA) Literature ${ }^{1}$ online. The data for this study is derived from my thesis research on how narratives of sexuality found in YA Literature have informed the sexual lives of young women readers. Reading online on a variety of platforms, such as fanfiction sites like Archive of Our Own (AO3) as well as sites that feature amateur fiction such as Tumblr and literotica.com, was a major theme that emerged from the interviews conducted for this project. The findings reveal that young women tend to seek out fiction in online spaces when they have questions or desires that are not addressed in conventional YA Literature. These readers reported that, from an early age, they sought out literature online that had explicit sexual content or focused on non-normative topics such as LGBTQ relationships. They also identified comments sections as a significant aspect of their online reading experience, which led to a sense of belonging to a reading community that is transparent, supportive and constructive about topics of sexuality.

\section{Methodology}

Louise Rosenblatt's (1978) transactional theory of reading emphasises the necessity of considering the author, text and reader in understanding the experience of reading; reading is an event where the interpretation of a text is wrought within a matrix of the author's words and the reader's own life experience. Therefore, two primary methods of data collection are used for this study. It includes a textual analysis of a piece of Harry Potter slash fanfiction ${ }^{2}$ to exemplify key differences and similarities between fanfiction and published YA Literature in regards to content, form, theme, language, and authorship. In tandem, it includes responses from phenomenological semi-structured interviews (Seidman, 2013) that were conducted with 10 female participants for my thesis research on young women's experiences reading sexually-themed YA Literature. Participants are between the ages of 19 and 24 and vary in the type of texts they read, sexual orientation, ethnicity, and sexual/relationship experience. This data reveals how reading online fanfiction and amateur fiction informs their sexual lives. 
The major theoretical underpinnings of this study come from the fields of Reading Studies, Sex Education, and Literary Criticism. Predominantly, this paper contributes to a genealogy of research on readers and reading such as the works of Louise Rosenblatt (1938;1978), Janice Radway (1984), Catherine Ross (1999) and Paulette Rothbauer (2004). All of these studies emphasise the reader's perspective in the reading experience, which includes the process of aesthetic reading, ${ }^{3}$ how readers respond to different works of fiction, and fiction as a source of everyday life information. These studies lend to a general emphasis on highlighting the experiences of readers in making meaning of texts and they inform both my interview methodology and the analysis of the texts themselves.

Seminal works from Sex Education provide a framework for analysing codes of sexuality found within sexuality-themed fiction and evaluating texts as positive sources of information on sexuality. In particular, this study is informed by the research of Michelle Fine (1988), Deborah Tolman (2002), and Louisa Allen (2004) on the discourse of desire, which identifies the discourses of sexuality that either disenfranchise or empower young people (especially young women) when they learn about their sexuality.

In addition, the work of Linda K. Christian-Smith (1990), Robert Seelinger Trites (2000), and Lydia Kokkola (2013) in the field of YA Literature studies provide this study with an approach to understanding sexuality in YA Literature that is situated within theories of childhood, adolescent sexuality, and gender. From a critical perspective, these works identify the existing patterns of power, repression, and socialization found within sexuality-themed YA Literature. This study also incorporates general research on fanfiction and fan communities (see for example Busse, 2017) as well as studies that specifically examine Harry Potter slash fanfiction such as Catherine Tosenberger's (2008) “Homosexuality at the Online Hogwarts” and Jennifer Duggar’s (2017) “Revising Hegemonic Masculinity”.

\section{Findings and Discussion}

Participants in the study who read online fiction were often motivated to do so because they were seeking an alternative to conventional published YA Literature. These readers were specifically seeking literature that better reflected their diverse reading interests, such as LGBTQ, BDSM, and other non-normative based relationships. Indeed, as Tosenberger (2008) and Duggar (2017) have discussed, open-source repositories such as AO3 allow amateur authors the freedom to create and share works of fiction that bypass constraints on content and language that are often imposed by the book publishing industry, especially books written for a young adult audience. As participant Madeline expressed, "I find [fanfiction authors] make them so much more real because it's not an author, right? It's just someone writing a book and throwing it online. So, they don't have to follow any of the, you know...they have to use certain words. It's just raw, whatever they want to write on the page". Most notably, readers felt that because fanfiction and other online amateur fiction is written by "normal" people (not published authors) there is: a greater degree of authenticity, wider range of topics on sexuality, more use of

explicit/transparent descriptions of sex, and a more realistic (as opposed to idealistic) outlook on relationships.

As an example, participant Andie viewed fanfiction as an alternative to "cookie cutter" heterosexual narratives found in many conventional YA novels. Her main reading interest was fanfiction that focused on the slash relationship between characters Harry Potter and Draco 
Malfoy ${ }^{4}$ from J.K. Rowling's Harry Potter series. Reading sexually-explicit fanfictions about same-sex relationships gave Andie a positive outlook on queer relationships. She told me: "It makes [queer relationships] so much less taboo. If you don't know what it actually is, it's this forbidden thing you don't know about or anything. And now I see it I'm like, 'Yeah, whatever...it's beautiful, they're so cute together'”. Reading these stories was personally significant to Andie as, at the time, she was exploring her own bi-sexuality in her real life and she felt uncomfortable discussing this with her friends and family. It was an important aspect of her reading experience that she found queer relationships to be normalised, embraced and discussed transparently in fanfiction communities. As she related in the interview, "When I read a fanfic that totally I can relate with and I love, and I'm like... somebody is on the same wavelength I am. I feel like...it’s not feeling alone”.

Similarly, participants who read online also emphasised the importance of comments sections, as a form of community, in validating their sexual desires and facilitating their learning on topics such as safe-sex and healthy relationships. For example, participant Sarah revealed "I think it's a wonderful setting [online]. I think it's always the comments sections that really interests me after reading a story...It's really also where I got a lot more sex education". Sarah told that she would read the comments section after every story she read and that the community often talked about complex and timely issues, such as consent, in a supportive and constructive way. Although reading offline can be a social practice, participants often reported that they felt uncomfortable talking to their friends about their reading interests or with discussing sexuality-themed books in a book club setting. Comments sections are a unique feature of online reading which, in many cases, especially surrounding the topic of sexuality, cannot be replicated with the solitary act of reading.

\section{Conclusion}

This paper contributes to the discussion of sexuality in Young Adult Literature in two significant ways. First, it adds to expanding the scope of study on sexuality in YA Literature to YA Literature that is found online. Second, it incorporates interview data on young women's experiences reading sexuality-themed literature online. Through the voices of these young women readers, this paper reveals the role of online fiction in their sexual lives and argues that these online spaces may ultimately contribute to the sexual empowerment of young women as it relates to the exploration and validation of their desires. For young women who feel as though their reading interests surrounding the topic of sexuality are not addressed within conventional published YA Literature, online fiction becomes a liberating alternative.

\section{References List:}

Allen, L. (2004). Beyond the birds and the bees: Constituting a discourse of erotics in sexuality education. Gender and Education, 16(2), 151-167

Busse, K. (2017). Framing fan fiction: Literary and social practices in fan fiction communities. Iowa City: University Of Iowa Press.

Christian-Smith, L.K. (1990). Becoming a woman through romance. New York: Routledge. 
Duggan, J. (2017). Revising hegemonic masculinity: Homosexuality, masculinity, and youthauthored Harry Potter fanfiction. Bookbird: A Journal of International Children's Literature, 55(2), 38-45.

Fine, M. (1988). Sexuality, schooling, and adolescent females: The missing discourse of desire. Harvard Educational Review, 58(1), 29-53.

Kokkola, L. (2013). Fictions of adolescent carnality: Sexy sinners and deliquent deviants. Amsterdam: John Benjamins Publishing Co.

Radway, J. A. (1984). Reading the romance: Women, patriarchy, and popular literature. Chapel Hill: University of North Carolina Press.

Rosenblatt, L. M. (1938). Literature as exploration. New York: D. Appleton-Century Co.

Rosenblatt, L. M. (1978). The reader, the text, the poem: The transactional theory of the literary work. Carbondale: Southern Illinois University Press.

Ross, C.S. (1999). Finding without seeking: The information encounter in the context of reading for pleasure. Information Processing \& Management, 35(6), 783-799.

Rothbauer, P. (2004). Finding and creating possibility: Reading in the lives of lesbian, bisexual and queer young women (Doctoral dissertation). Available from ProQuest Dissertations \& Theses Global. (305083607)

Seidman, I. (2006). Interviewing as qualitative research: A guide for researchers in education and the social sciences (3rd ed.). New York: Teachers College Press.

Tolman, D. L. (2002). Dilemmas of desire: Teenage girls talk about sexuality. Cambridge, Mass: Harvard University Press.

Tosenberger, C. (2008). Homosexuality at the online Hogwarts: Harry Potter slash fanfiction. Children's Literature, 36(1), 185-207.

Trites, R. S. (2000). Disturbing the universe: Power and repression in adolescent literature. Iowa City: University of Iowa Press.

\footnotetext{
${ }^{1}$ Literature that is written about teens in a distinctly teen voice.

${ }^{2}$ Hungry, a fanfiction short story written by birdsofshore on AO3. Set in the world of J.K. Rowling's Harry Potter, this canon-divergent short story spins a tale of romance between Harry Potter and his nemesis Draco Malfoy that blossoms into a sex-positive discovery of their mutual sexual attraction to one another. The term "slash" refers to texts that have been queered by depicting homoerotic relationships between characters (Duggan, 2017).

${ }^{3}$ According to Rosenblatt (1978): In aesthetic reading, "the reader's attention is centered directly on what he is living through during his relationship with that particular text” (p. 25) and is typically associated
} 
with reading literary works of art. In opposition, efferent reading is where there reader's attention is directed outward towards "concepts to be retained, ideas to be tested, actions to be performed after the reading of the text” (p. 24).

${ }^{4}$ This is a well-established genre of fanfiction known as "Drarry". 